\title{
Zuzana Goncarova,
}

Ph.D., Catholic University in Ruzomberok, Slovakia

email: zuzana.goncarova@ku.sk

Jana Pitekova,

Ph.D., Associate Professor, Catholic University in Ruzomberok, Slovakia

email: jana.pitekova@ku.sk

\section{Maria Vrablikova,}

Catholic University in Ruzomberok, Slovakia

email: maria.vrablikova@ku.sk

Correspondence author: zuzana.goncarova@ku.sk

\section{ASSESSMENT OF THE IMPACT OF SELECTED SATISFACTION PARAMETERS ON THE COMPETITIVENESS OF FAMILY TOURISM}

Abstract. The visitor, as the bearer of the demand for tourism services, is primarily a person with his natural desires. For many, a family business is a guarantee of a more helpful approach to meeting clients' expectations. The paper aims to analyze the dependence between selected parameters of customer satisfaction in two groups of tourist trade establishment or tourism companies. The first group consists of family businesses, which have long shown a higher level of satisfaction compared to traditional tourism companies. The second group are classic tourism companies. In both cases, the research interest is the impact of a change in the assessment of staff and a change in the evaluation of the price/quality ratio on the change in the overall evaluation of these two groups of companies. Authors assumed that satisfaction with the staff in family businesses has a more significant impact on overall satisfaction. The research sample consists of 44 non-family and 18 family businesses. The research includes: assessment of the staff, evaluation of the price/quality ratio and overall evaluation for 2018 and 2020 based on secondary data, calculation of changes (indices) of the parameters as the ratio of values in 2020 to 2018, partial correlation analyzes for individual years and compilation of final correlation matrix, in which is examined the correlation between the change in the overall assessment in family and non-family businesses and the correlation between the change in the price/quality ratio in family and non-family businesses. The basic methods include analysis, synthesis, induction, analogy, comparison, empiricism and Pearson's correlation coefficient from mathematical-statistical methods. The basic heuristic approach consists of professional literature on the subject matter and secondary sources obtained from the most important accommodation portal booking.com. In the synthesis of knowledge there are used empirical experience resulting from doing long-term business in the field of tourism of authors. As part of the compilation of the resulting correlation matrix, authors state that in non-family businesses both correlation coefficients are higher than in family ones. In contrast, in evaluating the relationship between the change of personnel, the value of Pearson's correlation coefficient is higher than 0.7 , so it is a strong dependence. Non-family businesses should pay more attention to the human factor. The barrier to fulfilment can be impersonal leadership and inflexible organizational structures. In family businesses, on the other hand, the selection of employees is based on mutual trust. The benefit of the paper is the distinction between family and non-family businesses from the customer's point of view, which is often a marginalized topic in theory and practice.

Keywords: competitiveness, correlation, customers' satisfaction, family business, non-family business, tourism.

Introduction. The human factor is irreplaceable in all businesses, but especially in small and mediumsized enterprises providing services. A special subgroup of small and medium-sized enterprises are family businesses, in which the position of two key market players (households and enterprises) is united into one unit. According to the recommendations of the European Commission Directive no. 2003/161/EC on the classification of enterprises by size, the folloving criteria are considered: the number of employees

Cite as: Goncarova, Z., Pitekova, J., \& Vrablikova, M. (2020). Assessment of the Impact of Selected Satisfaction Parameters on the Competitiveness of Family Tourism. Marketing and Management of Innovations, 4, 131-143. http://doi.org/10.21272/mmi.2020.4-10 
Z., Goncarova, J., Pitekova, M., Vrablikova. Assessment of the Impact of Selected Satisfaction Parameters on the Competitiveness of Family Tourism

(main criterion), annual turnover (secondary criterion) and balance sheet total (secondary criterion) (Markova, 2003). An overview of these parameters can be found in Table 1.

Table 1. Classification of SMEs in the European Union

\begin{tabular}{cccc}
\hline Category & Number of employees & $\begin{array}{c}\text { Annual turnover in } \\
\text { mil. EUR }\end{array}$ & $\begin{array}{c}\text { Balance sheet } \\
\text { total in mil. EUR }\end{array}$ \\
\hline Microbusiness & $0-9$ & less than 2 & less than 2 \\
Small business & $10-49$ & less than 10 & less than 10 \\
Medium-sized business & $50-249$ & less than 50 & less than 43 \\
\hline
\end{tabular}

Source: developed by the authors on the basis of (Markova, 2003).

In the Slovak Republic, according to Markova (2003), Subertova et al. (2009), Ubreziova et al. (2020) small and medium-sized enterprises, which usually also include family businesses characterized in the following subchapter, have the following advantages in comparison to big companies:

- a significant share in value-added;

- contributing to the creation of a social climate, to the employment, social and societal employment of various groups of the population;

- revitalization of historical centres, offering a wide range of services;

- contributing to the maintenance of a healthy environment by revitalization, resp. maintaining cultural and craft traditions;

- contributing to the stratification of society by ensuring a favourable socio-psychological atmosphere;

- dynamizing the market social order;

- stabilization of the structure of economic activity, the social structure of society and political structure.

According to Ahmad et al. (2020) small and medium-sized enterprises in contrast to large enterprises are characterized, in addition to the above facts, as businesses with a clearer organizational structure, more effective communication, fewer conflicts, faster application of the principles of corporate social responsibility (CSR), faster responses to market demands. The negative can be the lack of financial resources, which can affect the company, especially in the introduction of innovations, the purchase of new technology and the remuneration of employees. As many as $99.2 \%$ of active companies in Slovakia belonged to small and medium-sized enterprises. The share of small and medium-sized businesses in total employment is $59.5 \%$ (Belas et al., 2015). Within the market cycle, there is a mutual conditionality of the behaviour and actions of households and enterprises in the context of demand and supply in the markets of goods and services and factors of production. The family business combines these attributes, and the purpose of our research is to assess the impact of behaviour and actions of owners and at the same time employees of family businesses on the evaluation of family tourism businesses taff, compare them with classic (traditional) businesses and analyze the dependence of individual parameters of customer satisfaction evaluation. Two of the team of authors are also owners and managers of family tourism businesses, so it is possible to use the empirical methods well, and the results of the survey acquire practical application significance. For the last three years in a row, family businesses have shown about $5 \%$ higher satisfaction rates than traditional businesses. This article investigated which parameter - staff and price/quality ratio is statistically more significant. In the theoretical part, the paper points to the uniqueness of family businesses concerning classic (conventional) businesses with an emphasis on the position of the human factor in small and medium-sized tourism enterprises, the application part surveys 
Z., Goncarova, J., Pitekova, M., Vrablikova. Assessment of the Impact of Selected Satisfaction Parameters on the Competitiveness of Family Tourism

a selected sample of tourism enterprises in the High Tatras. Secondary data analysis is processed using the Pearson correlation coefficient. For evaluation of the acquired knowledge synthesis and induction are used.

Literature Review. The family business is still a marginalized topic in Slovakia. Therefore, terms such as family business or family entrepreneur are not defined in either Slovak or European legislation (Slovak Business Agency, 2014). Research by Strazovska, Strazovska and Kroslakova (2008) shows that in Slovakia, up to $71 \%$ of family businesses would welcome a law regulating family business.

According to Finnish professor Matti Koiranen, the first family business in the world was a company called Paradise, owned by Adam and Eva. Astrakhan et al. (2020) analyze the family business in terms of religion and spirituality. Religious (or, more broadly, spiritual) values significantly change organizational decision-making and ethical behaviour. Family businesses, which are a type of values-based organization, provide ample scope for religious beliefs that influence family, business, and individual decisions (Figure 1).

\begin{tabular}{|c|c|c|c|}
\hline Values, Norms \& Goals & $\begin{array}{c}\text { Religious Values and } \\
\text { Principles }\end{array}$ & $\begin{array}{c}\text { Faith- Led } \\
\text { Organizational practice }\end{array}$ & $\begin{array}{l}\text { Business \& Family } \\
\text { Outcomes }\end{array}$ \\
\hline Business System & $\begin{array}{ll}\text { - } & \text { Religious Values } \\
& \text { Formation } \\
\text { - } & \text { Religious Values } \\
& \text { Prioritization } \\
\text { - } & \text { Religious Values } \\
& \text { Interpretation } \\
\text { - } & \text { Religious Values } \\
\text { - } & \text { Imprinting } \\
\text { - } & \text { Religious Identity } \\
& \text { Formation } \\
\end{array}$ & $\begin{array}{ll}- & \text { Spiritual Leadership } \\
\text { - } & \text { Ethical Business } \\
& \text { Behavior }\end{array}$ & $\begin{array}{ll}\text { - } & \text { Performance } \\
\text { - } & \text { Market Valuation } \\
\text { - } & \text { Work-life conflict } \\
& \text { and employee } \\
& \text { commitment } \\
\text { - } & \text { Longevity } \\
\text { - } & \text { Religious values } \\
& \text { preservation }\end{array}$ \\
\hline
\end{tabular}

Figure 1. Religious/spiritual impact on the family business

Source: developed by the authors on the basis of (Astrachan et al., 2020).

Ethical management of a family business could also be applied in the form of the principles of the Social Doctrine of the Church. Based on such behavior, it could be seen in ethical companies, the goal is primarily customer satisfaction and profit is a reward for honest work (Pitekova, 2017).

Strazovska, Strazovska and Kroslakova (2008) define a family business as «an enterprise in which ownership belongs to a family member, is managed by a family member or the descendant of the founder», and thus «is related to the institution of family and marriage». The authors also found that the vast majority of family businesses are set up as small and medium-sized enterprises, and research in the world shows that more than $2 / 3$ of family businesses are small and medium-sized enterprises, with small businesses predominating. In order to be considered a family business, a business must meet at least one of the following criteria:

- the owner considers his business to be a family business;

- the owner intends to hand over his business to a close relative; 
- in addition to the owner, another family member works as a full-time employee, which is part of the daily management process of the company (Strazovska et al., 2009).

Currently, there are 2 defining approaches to family businesses, which serve to distinguish family businesses from non-family ones, namely:

- component of ivolvement approach - focuses on measurable assumptions that distinguish family businesses from non-family ones, the focus is on combinations of elements that exist only in the family business and reflect the involvement of the family in the business (family ownership, succession), most authors focuses on these elements/components, such as family ownership;

- an «essence approach» - the aim is to observe behaviour that is specific to family businesses and to assess the benefits of the family for this business compared to the situation if it were not of a family character (Klein, 2004).

Family businesses almost always reflect family relationships. Based on experience, Strazovska et al. (2009), Heskova and Vojtko (2008) distinguishes 3 types of family companies, namely:

- parental (may apply an authoritarian, protectionist or democratic style of management);

- marital (joint establishment by spouses or acquisition by marriage);

- relatives (e.g. fraternal, sisterly, in terms of development it is the riskiest, because there is the highest risk of conflict).

According to Moresova and Sedliacikova (2017), one of the basic functions of the family is the socioeconomic function. It understands the family as an important element in the development of the economic system of society. Its members are involved in the production and non-production spheres in the performance of a certain profession, and at the same time the family itself becomes a major consumer on which the market is highly dependent. Family business brings many advantages and disadvantages. The benefits include greater trust and reliability, financial benefits, independence, employment of family members, family cohesion, easier communication, leaving a profit to the family, better working relationships, flexibility, working on one's own, building and enhancing family property, motivation for one's own future (Strazovska et al., 2009; Strazovska, Strazovska, KroSlakova, 2008). Among the benefits of family business in the field of economy and social development are following:

- a purposeful combination of own and foreign sources of financing as a prevention of indebtedness, which ensures attractiveness for future generations;

- family businesses have a particular interest in local and regional development;

- in family businesses, family values are transferred to the business;

- family business owners are more interested in satisfaction, whether of customers or employees, informal relationships improve social function in the family business;

- $\quad$ in family businesses, performance depends mainly on intellectual capital and the so-called Socioemotional Wealth perspective (SEW) (Kucerova and Smardova, 2016; Zahra, 2016; Moresova, Sedliacikova, 2017; Bujan, 2020; Ramirez et al., 2020). The main disadvantages include the transfer of work matters to privacy, the connection of business to the family, frequent disagreements at work leading to a «quiet household», undefined division of competencies, failure to require the necessary qualifications from family members, the trend of preferring family members to management positions, lack of capital, liability of all family property (if the owner is a self-employed person), burden on the family budget in case of business failure, constant presence of family members in the workplace (submarine disease), irregular wages, self-esteem and thus oversight of the market situation and succession problem (Strazovka et al. , 2009; Strazovska et al., 2008; Hanson et al., 2019). The positives and negatives of family business are also addressed in Gibb (2018), who created a matrix composed of 4 quadrants (4 types of family businesses - Figure 2), where he - on the vertical axes - compared the advantages and disadvantages of family business (assets \& liabilities) and on the horizontal axes the size of agency costs. Among the advantages he included e.g. social ties, rational financing and among the disadvantages e.g. tolerance of 
Z., Goncarova, J., Pitekova, M., Vrablikova. Assessment of the Impact of Selected Satisfaction Parameters on the Competitiveness of Family Tourism

low qualifications of family members, nepotism, prioritization of self-interests. Agency theory mentions the differences between the goals of owners and managers (agents).

\begin{tabular}{|c|c|c|}
\hline \multirow{3}{*}{$\begin{array}{l}\text { Assets } \\
\text { Liabilities }\end{array}$} & High agency costs & Low agency costs \\
\hline & Professional Family Firm & Clean Family Firm \\
\hline & Self- interested family firm & Mom and pop family firm \\
\hline
\end{tabular}

Figure 2. Matrix of family business

Sources: developed by the authors on the basis of (Gibb ,2018).

Stanley et al. (2019), who distinguishes in the matrix the strength of family influence and the life cycle of the company, have a different approach to the classification of family businesses. Based on the research hypotheses in a sample of 684 family businesses, they determined the main characteristics of these businesses as well as the characteristics of the «hybrid» family business (Figure 3).

\begin{tabular}{|c|c|c|c|}
\hline & Earlier & Family Life Cycle & Later \\
\hline Lower & $\begin{array}{l}\text { Profile 1: Developing Non-family } \\
\quad \text { Firm } \\
\text { - } \quad \text { Low family ownership } \\
\text { - } \quad \text { No board of Directors } \\
\text { - } \quad \text { Small ( } 50 \text { employees) } \\
\text { (mostly) } \\
\text { - } \quad \text { First-generation firms }\end{array}$ & & No Firms \\
\hline $\begin{array}{c}\text { Family } \\
\text { Influence }\end{array}$ & & $\begin{array}{ll} & \text { Profile 2: Hybrid } \\
\text { - } & \text { High family ownership } \\
\text { - } & \text { Family CEO } \\
\text { - } & \text { Board of Directors } \\
\text { - } & \text { Small ( } 150 \text { employees) } \\
\text { - } & 50 \% \text { first-generation firms }\end{array}$ & \\
\hline Higher & $\begin{array}{ll}\text { Profile 3: Young Family Firms } \\
\text { - } & \text { High family ownership } \\
\text { - } & \text { Family CEO } \\
\text { - } & \text { No Board of Directors } \\
\text { - } & \text { Small ( } 50 \text { employees) } \\
\text { - } & \text { First-generation firms }\end{array}$ & & \begin{tabular}{ll} 
& \multicolumn{1}{c}{ Profile 4: Dynasty } \\
- & High family ownership \\
- & Family CEO (mostly) \\
- & Board of Directors \\
- & Large (> 50 employees \\
- & Later (i.e. not first) generation
\end{tabular} \\
\hline
\end{tabular}

Figure 3. Family business according to family impact and life cycle

Sources: developed by the authors on the basis of (Stanley et al., 2019).

According to a study by Sedliacikova et al. (2020), family businesses also have many other specifics, namely in the field of organization and communication. As many as $68.10 \%$ of Slovak family businesses do not have a precisely defined organizational structure, $53.15 \%$ decide based on a joint discussion in the family, and $61.40 \%$ of family businesses state medium coordination between their family and business goals.

Andreini et al. (2020) examined the benefits of a family business for customers in their review study of containing 83 scientific papers. These were social and cultural aspects at the micro-, meso- and macrolevels. In some cases, family businesses have been able to create and reach new customer markets that are characterized by identification with the community. 
In the family business, it is also necessary to harmonize the creation of a business plan and strategy, because the interests of the family determine its form. «These interests include future cooperation of the family, independence of its members, the volume of financial resources that the family needs to obtain from the business process, the coexistence of older and younger family members, the satisfaction of older members with the results achieved by younger members» (Strazovska et al., 2008).

According to a survey conducted by the Slovak Business Agency (2014) at the beginning of the business, family businesses have problems mainly with access to finance and excessive administrative burden. During the life cycle of family businesses, their problems also change. One of the problems of the parent companies, in particular, was the issue of succession, i.e. the preparation for their transition to the young generation, which is intensified with the increasing age of the founders of the family businesses. Moresova et al. $(2018,2019)$ examined in their studies the positive and negative determinants of the external and internal environment of Slovak family businesses. The order of determinants of the external environment was as follows: state bureaucracy (threatens up to $94.7 \%$ ), tax burden, legislative instability, low law enforcement, administrative burden and low support. Only $14.3 \%$ of family businesses perceive the external environment positively. Within the internal environment, the order of determinants that have a positive impact is as follows: the family's efforts to increase assets and expand them (69.7\%), family cohesion and the intertwining of family-business relations. On the contrary, $28.9 \%$ of family businesses consider competencies between family members to be unclear. Fear of the termination of the family tradition in the form of succession is a negative factor for $26.8 \%$ of family businesses. Although the space for doing business has been created for young family members, they have the appropriate education, language skills, creativity and innovation, they are often not interested in continuing family business. This characteristic of current successors meets the main attributes of Generation Y (born 1978-1994, sometimes until 2000), which, according to sociologists and also Kotler and Keller (2007) and Davidaviciene et al. (2019), is predatory, urban style, idealistic, independent and less conservative than Generation X (1965-1978). With their character traits, attitude to work and consumer behaviour, this generation is closer to the Baby boomers generation $(1946$ - 1964) than to the X generation. However, foreign research shows that «only $5-15 \%$ of family businesses survive into the third generation in the hands of the descendants - founders. Other statistics indicate that $30 \%$ of family businesses survive only in the second generation, $10-15 \%$ survive in the third generation, and $3-5 \%$ operate in the fourth generation» (Serina, 2011; Ahmad et al., 2020). Sedliacikova et al. (2020) states that currently, 2 generations work in $70.50 \%$ of Slovak family businesses, and 1 generation in $27.90 \%$ (founders). Tourism companies provide services. It is appropriate to supplement the theoretical background with this dimension. Kozak and Stankova (2008,) define a service as «an activity that one party can offer to the other. It is completely intangible and does not create any ownership. Its implementation may or may not be linked to a physical product». It is complicated to find pure manufacturing companies and pure service companies, and thus they can move in the following spectrum:

- purely tangible products - the product is not accompanied by any services (e.g. soap, salt, toothpaste);

- tangible products accompanied by services - the offer consists of a product accompanied by one or more services, the aim of the services is to increase the attractiveness of products, and without them, the company's turnover would significantly decrease (e.g. custom wood production, IT production, cars);

- hybrid - the offer consists of a balanced ratio of product and service (e.g. service in restaurant facilities);

- predominant services with a small share of a tangible product or other services (e.g. airline services, where food and drink are also offered as part of the transport);

- pure service - the offer consists primarily of service (e-g- childcare, psychotherapy, massage) (Kotler andKeller, 2007; Kozak and Stankova, 2008; Stefko et al., 2013; Rasovska and Ryglova, 2017). 
According to Payne (1996) and Gucik (2011), the basic features of services include intangibility (abstract character, where the supplier must «materialize intangible», e.g. office equipment, the image of workers, etc.), indivisibility (production and consumption take place simultaneously in the presence of the customer), variability (dependence on the human factor and its current performance) and transmissibility (non-storage). Tourism is a sector that accounts for a substantial part of GDP. In the case of tourism services, other features include the grouping of disparate services and goods and the interdependence of their producers (symbiosis of free and economic goods, the need for cooperation of producers), ties to the destination (impossibility to try in advance), complexity and complementarity (satisfying a set of multiple needs, where one need evokes another, the product must consist of several sub-products) and the seasonal nature of demand (due to natural and social factors). In the consciousness of clients within the V4, it is most associated with accommodation services. (Gucik et al., 2010; Orieska, 2010; Bacík et al., 2020). According to Gucik et al. (2006), Porter (2008) and Ravar and lorgulescu (2013), the source of the competitive advantage of tourism services are company's strengths compared to the competition, business resources and skills (value chain, economy, know-how), with material resources being the easiest to imitate and skills (human capital, staff) being the most difficult to imitate. In the value chain in terms of tourism, the emphasis is on the provision of services, on direct contact with the client. Customer satisfaction and the overall atmosphere in the provision of services greatly affects their subjective evaluation.

Methodology and research methods. The paper aims to analyze the dependence between selected parameters of customer satisfaction in two groups of tourism companies. The first group consists of family businesses, which have shown a higher level of satisfaction during a long period compared to traditional tourism businesses (Pitekova and Goncarova, 2018). The second group are classic tourism companies. In both cases, the research interest is the impact of a change in the evaluation of staff and a change in the evaluation of the price/quality ratio on the change in the overall evaluation of these two groups of companies. The research hypothesis is that satisfaction with the staff in family businesses has a more significant impact on overall satisfaction. In terms of methodology, the research is composed of these steps:

- identification of the research sample (44 non-family and 18 family businesses);

_ staff evaluation, evaluation of the price/quality ratio and overall evaluation for the years 2018 and 2020 based on secondary data;

- calculation of changes (indices) of the mentioned parameters as the ratio of values in 2020 to 2018;

- partial correlation analyzes of individual types of businesses for individual years;

- compilation of a correlation matrix in which is examined the correlation between the change in the overall assessment in family and non-family businesses and the correlation between the change in the price/quality ratio in family and non-family businesses.

The basic methods include analysis, synthesis, induction, analogy, comparison, empiricism, desk data processing (desk research) and Pearson's correlation coefficient from mathematical-statistical methods. The basic heuristic base consists of professional literature on the subject matter and secondary sources obtained from the most important accommodation portal booking.com. In the synthesis of knowledge, authors use our own empirical experience from many years of business in the field of tourism.

Results. Under the survey purposes, the family business is considered to be only the one in which its owners come into direct contact with clients, i.e. visitors to the accommodation facility. These were usually small accommodation facilities. There are quite a few such «family businesses» in the High Tatras (the survey was conducted in the High Tatras and its surroundings), but it is not easy to identify them for several reasons. First of all, most small accommodation establishments of this type do not operate based on a trade license, nor as a limited liability company (or another kind of company), as they do not show a 
sufficiently high income. The business of accommodation services is usually a supplementary, not the main income of the family. They provide accommodation in the privacy of family homes, which often makes it impossible to set aside business costs. In this case, the costs are most often part of the family budget. It follows that the family's costs are higher, as they also include the costs of operating the rented shortterm accommodation. These "family businesses» invest little time and money in marketing communications. That is understandable because their income could be included in the so-called shadow economy. In the frame this research, it was selected registered business entities that also meet the requirement of contact between the business owner and the client. A total of 18 small and medium-sized family businesses were surveyed. On the other hand, It was chosen business entities where the owner (whether a private person or persons or shareholders) is rather anonymous and does not come into daily contact with the client. Authors identified 44 such companies to meet the objective of the paper. In total, the survey was conducted in 62 companies. When processing the paper, authors proceeded from the hypothesis that there is a dependence between the change in the assessment of staff or a change in the evaluation of the price/quality ratio and a change in the overall assessment of the quality of accommodation services. For quantification is used the Pearson correlation coefficient to verify the hypothesis. The staff and the price/quality ratio were rated in the range from 0 to 10 points. With the growing number of points, client satisfaction with the approach of staff and the price/quality ratio in accommodation facilities also increased. Also, the overall evaluation of the quality of services was set in the range from 0 to 10 points. A higher number of points meant greater satisfaction with the quality of services. Subsequently, changes were recorded in the assessment of staff, in the evaluation of the price/quality ratio as well as in the general assessment of service quality in 2020 compared to 2018 . The change could have a positive or negative value depending on whether there was an improvement during those years in the evaluation of the staff approach, in the evaluation of the price/quality ratio and in the overall evaluation of services (positive values of changes) or to the deterioration in the given indicators (negative values of changes) from the point of view of clients of accommodation establishments. The findings for individual accommodation facilities were recorded as "change 2018-2020» and subsequently correlated with changes in the quality of staff access and price/quality ratio with changes in the overall assessment (Table 2, Table 3).

Pearson's correlation coefficient was calculated separately for classical accommodation establishments and family-type businesses. It is clear from the results that the dependence of the change in the overall rating on the change in the staff rating is higher in traditional accommodation establishments. Thus, the correlation coefficient is rounded to 0.729 . On the contrary, the dependence of the change in the overall assessment on the change in the staff assessment is lower for family enterprises. The correlation coefficient is rounded to 0.587 . The result is that family businesses are not as dependent on the development of staff assessment as traditional accommodation businesses providing accommodation services. According to these results, there is overall higher satisfaction in family businesses, which may reflect the sensitive and humane approach of the owners, who come into direct contact with the client. It could be stated that during the two years, between 2018 and 2020, there was a deterioration in the overall evaluation of 16 classical enterprises, which represents $36.4 \%$ of all monitored 44 classical businesses. At the same time, there was a deterioration in the case of 5 family businesses, which represents $27.8 \%$ of the total number of 18 family businesses.

It follows from the above that, in terms of the development of the overall assessment, traditional enterprises perform worse than small and medium-sized family businesses. In terms of the development of staff assessment during the two years, 12 out of 44 traditional companies deteriorated, which is $27.3 \%$. In the staff assessment, 3 out of 18 small and medium-sized family businesses deteriorated, which represents $16.7 \%$. 
Z., Goncarova, J., Pitekova, M., Vrablikova. Assessment of the Impact of Selected Satisfaction Parameters on the Competitiveness of Family Tourism

Table 2. Analysis of non-family companies

\begin{tabular}{|c|c|c|c|c|c|c|c|c|c|c|}
\hline \multirow[b]{2}{*}{ Tourism company } & \multirow[b]{2}{*}{ Class } & \multicolumn{6}{|c|}{ Evaluation criteria } & \multicolumn{3}{|c|}{ Index 2018-2020 } \\
\hline & & $\begin{array}{l}\text { pers. } \\
2018\end{array}$ & $\begin{array}{l}\text { pers. } \\
2020\end{array}$ & $\begin{array}{l}\text { pr./q. } \\
2018\end{array}$ & $\begin{array}{l}\text { pr./q. } \\
2020\end{array}$ & $\begin{array}{l}\text { final } \\
2018\end{array}$ & $\begin{array}{l}\text { final } \\
2020\end{array}$ & pers. & $\mathrm{pr} . / \mathrm{q}$. & final \\
\hline Hotel sorea hutník & $* * *$ & 8,4 & 8,6 & 8,6 & 8,4 & 8,6 & 8,6 & 0,2 & $-0,2$ & 0 \\
\hline Grandhotel s. Smokovec & $* * * *$ & 9,1 & 9,2 & 8,4 & 8,5 & 9,1 & 9,1 & 0,1 & 0,1 & 0 \\
\hline Mountain hotel bilíkova chata & $* *$ & 8,9 & 9 & 8,6 & 8,8 & 8,8 & 8,6 & 0,1 & 0,2 & $-0,2$ \\
\hline Hotel avalanche & $* * *$ & 9,2 & 8,9 & 8,5 & 8,5 & 8,7 & 8,6 & $-0,3$ & 0 & $-0,1$ \\
\hline Hotel euforia & $* * *$ & 9 & 9 & 8,2 & 7,9 & 8,2 & 7,9 & 0 & $-0,3$ & $-0,3$ \\
\hline Grand hotel bellevue & $* * * *$ & 8,4 & 8,4 & 7,6 & 7,5 & 8,3 & 8,4 & 0 & $-0,1$ & 0,1 \\
\hline Hotel villa siesta & $* * *$ & 8,9 & 8,5 & 8,2 & 7,4 & 8,7 & 8,2 & $-0,4$ & $-0,8$ & $-0,5$ \\
\hline Horský hotel sliezsky dom & $* * * *$ & 9,2 & 9 & 8,4 & 8,3 & 9,3 & 9,2 & $-0,2$ & $-0,1$ & $-0,1$ \\
\hline Atrium hotel & $* * *$ & 9,1 & 9 & 8,1 & 8 & 8,8 & 8,6 & $-0,1$ & $-0,1$ & $-0,2$ \\
\hline Horizont resort & $* * * *$ & 9,2 & 9,3 & 8,6 & 8,5 & 9,1 & 9,1 & 0,1 & $-0,1$ & 0 \\
\hline Kukucka mountain hotel & $* * * *$ & 8,7 & 9,1 & 7,9 & 8,2 & 8,8 & 8,9 & 0,4 & 0,3 & 0,1 \\
\hline Hotel sasnka & $* *$ & 8,8 & 9,2 & 7,9 & 8,4 & 8,1 & 8,5 & 0,4 & 0,5 & 0,4 \\
\hline Penzion fantazia & $* * *$ & 9,5 & 9,4 & 9,4 & 9,4 & 9,4 & 9,4 & $-0,1$ & 0 & 0 \\
\hline Hotel slovan & $* * *$ & 8,9 & 8,8 & 7,8 & 7,6 & 8,6 & 8,5 & $-0,1$ & $-0,2$ & $-0,1$ \\
\hline Hotel sorea titris & $* * *$ & 8,1 & 8,6 & 8,1 & 7,9 & 8,3 & 8,4 & 0,5 & $-0,2$ & 0,1 \\
\hline Hotel tatry & $* * *$ & 8,8 & 8,4 & 7,9 & 7,8 & 8,5 & 8,1 & $-0,4$ & $-0,1$ & $-0,4$ \\
\hline Hotel amalia & $* * *$ & 9 & 9,2 & 8,4 & 8,8 & 8,9 & 9 & 0,2 & 0,4 & 0,1 \\
\hline Hotel lomnica & $* * * *$ & 9,6 & 9,6 & 9 & 8,9 & 9,6 & 9,5 & 0 & $-0,1$ & $-0,1$ \\
\hline Hotel rysy & $* * *$ & 7,3 & 7,4 & 6,7 & 6,8 & 7 & 7,1 & 0,1 & 0,1 & 0,1 \\
\hline Wellness hotel borovica & $* * * *$ & 9,5 & 9,3 & 8,6 & 8,5 & 9,3 & 9,1 & $-0,2$ & $-0,1$ & $-0,2$ \\
\hline Hotel fis & $* * *$ & 9,1 & 9,2 & 8 & 8,2 & 8,6 & 8,7 & 0,1 & 0,2 & 0,1 \\
\hline Hotel toliar & $* * *$ & 8,8 & 8,9 & 8,3 & 8,5 & 8,7 & 8,8 & 0,1 & 0,2 & 0,1 \\
\hline Hotel spolcentrum & $* * *$ & 8,5 & 8,6 & 8,8 & 8,9 & 8,6 & 8,7 & 0,1 & 0,1 & 0,1 \\
\hline Hotel aquacity mountain view & $* * * *$ & 8,6 & 8,8 & 7,8 & 8 & 8,5 & 8,7 & 0,2 & 0,2 & 0,2 \\
\hline Hotel satel & $* * *$ & 8,7 & 8,9 & 8,1 & 8,3 & 8,1 & 8,2 & 0,2 & 0,2 & 0,1 \\
\hline Garni hotel tatramonti & $* * *$ & 9,4 & 9,4 & 9,2 & 9,3 & 9,3 & 9,2 & 0 & 0,1 & $-0,1$ \\
\hline Grand hotel kempinski & $* * \star * *$ & 9,3 & 9,6 & 8,5 & 8,8 & 9,4 & 9,6 & 0,3 & 0,3 & 0,2 \\
\hline Hotel tatranec & $* *$ & 7,9 & 7,8 & 7,1 & 7,9 & 7,1 & 7,3 & $-0,1$ & 0,8 & 0,2 \\
\hline Garni hotel velický zamocek & ** & 9,4 & 9,6 & 8,8 & 8,8 & 8,9 & 8,9 & 0,2 & 0 & 0 \\
\hline Horský hotel popradske pleso & * & 8,7 & 8,7 & 8,5 & 8,2 & 8,6 & 8,7 & 0 & $-0,3$ & 0,1 \\
\hline Tatra hotel & $* * *$ & 8,6 & 8,6 & 8,2 & 8,2 & 8,2 & 8,1 & 0 & 0 & $-0,1$ \\
\hline Boutique hotel fortuna & $* * *$ & 8,7 & 8,9 & 8,2 & 8,7 & 8,5 & 8,7 & 0,2 & 0,5 & 0,2 \\
\hline Hotel aquacity seasons & $* * * *$ & 8,9 & 8,9 & 7,9 & 7,9 & 8,5 & 8,7 & 0 & 0 & 0,2 \\
\hline Hotel europa & $* * * *$ & 8,6 & 9 & 8 & 8,5 & 8,5 & 8,8 & 0,4 & 0,5 & 0,3 \\
\hline Hotel poprad & $* * *$ & 8 & 8,2 & 7,8 & 7,8 & 7,8 & 7,8 & 0,2 & 0 & 0 \\
\hline Hotel gerlach & $* * *$ & 7,7 & 8 & 7,1 & 6,3 & 7,1 & 7,1 & 0,3 & $-0,8$ & 0 \\
\hline Hotel crocus & $* * * *$ & 8,7 & 8,9 & 8,1 & 8,3 & 8,8 & 8,9 & 0,2 & 0,2 & 0,1 \\
\hline Hotel 63 & $* * *$ & 9,7 & 9,5 & 9,2 & 9,2 & 9,4 & 9,3 & $-0,2$ & 0 & $-0,1$ \\
\hline Hotel solisko & $* * * *$ & 8,9 & 8,9 & 8,1 & 7,9 & 8,9 & 8,8 & 0 & $-0,2$ & $-0,1$ \\
\hline Grand hotel praha & $* * * *$ & 9 & 9,2 & 8,2 & 8,4 & 8,9 & 9,1 & 0,2 & 0,2 & 0,2 \\
\hline Pension villa kunerad & $* * *$ & 9,6 & 9,4 & 9,1 & 9 & 9,3 & 9,1 & $-0,2$ & $-0,1$ & $-0,2$ \\
\hline Aplend b\&b julia & $* * *$ & 9,2 & 9,2 & 8,9 & 8,9 & 9,1 & 9 & 0 & 0 & $-0,1$ \\
\hline Apartmanový dom família & $* * *$ & 9,2 & 9,3 & 9,4 & 9,2 & 9,2 & 9,3 & 0,1 & $-0,2$ & 0,1 \\
\hline Hotel sobota & $* * *$ & 9,2 & 9,1 & 8,7 & 9 & 8,9 & 8,9 & $-0,1$ & 0,3 & 0 \\
\hline average & & 8,864 & 8,92 & 8,659 & 8,325 & 8,664 & & & & \\
\hline
\end{tabular}

Source: developed by the authors. 
Z., Goncarova, J., Pitekova, M., Vrablikova. Assessment of the Impact of Selected Satisfaction Parameters on the Competitiveness of Family Tourism

Therefore, it is clear that family businesses perform better than traditional businesses in terms of the development of valuations over time. In the evaluation of the price/quality ratio, between 2018 and 2020, there was a deterioration in 17 traditional enterprises, which is $38.6 \%$ of the total number, and in 5 family enterprises, which represents $27.8 \%$ of the total number.

Table 3. Analysis of family companies

\begin{tabular}{|c|c|c|c|c|c|c|c|c|c|c|}
\hline \multirow[b]{2}{*}{ Tourism company } & \multirow[b]{2}{*}{ Class } & \multicolumn{6}{|c|}{ Evaluation criteria } & \multicolumn{3}{|c|}{ Index 2018-2020 } \\
\hline & & $\begin{array}{l}\text { pers. } \\
2018\end{array}$ & $\begin{array}{l}\text { pers. } \\
2020\end{array}$ & $\begin{array}{l}\text { pr./q. } \\
2018\end{array}$ & $\begin{array}{l}\text { pr./q. } \\
2020\end{array}$ & $\begin{array}{l}\text { final } \\
2018\end{array}$ & $\begin{array}{l}\text { final } \\
2020\end{array}$ & pers. & $\mathrm{pr} . / \mathrm{q}$. & fina \\
\hline Vila anna & $* * *$ & 9,9 & 9,9 & 9,8 & 9,7 & 9,8 & 9,8 & 0 & $-0,1$ & 0 \\
\hline Guesthouse pavilond & $* * *$ & 9,8 & 9,7 & 9,5 & 9,2 & 9,5 & 9,3 & $-0,1$ & $-0,3$ & $-0,2$ \\
\hline Penzion vila park *** & *** & 9,6 & 9,6 & 9 & 8,6 & 9,3 & 9,2 & 0 & $-0,4$ & $-0,1$ \\
\hline Penzion tatrasport zampa *** & $* * *$ & 9,5 & 9,7 & 9,1 & 9,3 & 9,6 & 9,6 & 0,2 & 0,2 & 0 \\
\hline Penzion pleso & ** & 9,7 & 9,7 & 8,8 & 8,8 & 9,1 & 9,2 & 0 & 0 & 0,1 \\
\hline Pension aqualand & $* * *$ & 9,3 & 9,3 & 8,4 & 8,7 & 8,5 & 8,6 & 0 & 0,3 & 0,1 \\
\hline Penzion raimund ${ }^{* * *}$ & *** & 9,6 & 9,7 & 8,9 & 8,9 & 9 & 9,1 & 0,1 & 0 & 0,1 \\
\hline Villa tatran & ** & 9,2 & 9,3 & 9,2 & 9,4 & 9,3 & 9,2 & 0,1 & 0,2 & $-0,1$ \\
\hline Penzion slavia & ** & 8,3 & 8,5 & 8,1 & 8,3 & 7,9 & 8,1 & 0,2 & 0,2 & 0,2 \\
\hline Villa filip & $* * *$ & 9,6 & 9,6 & 9,4 & 9,6 & 9,5 & 9,6 & 0 & 0,2 & 0,1 \\
\hline Apartmany panorama $10 x-90 x$ & $* * * *$ & 9 & 8,9 & 8,7 & 8,6 & 9,2 & 9 & $-0,1$ & $-0,1$ & $-0,2$ \\
\hline Penzion u alzbetky & $* * *$ & 9,6 & 9,6 & 9,3 & 9,3 & 9,4 & 9,3 & 0 & 0 & $-0,1$ \\
\hline Penzion darinka & $* \star *$ & 9,7 & 9,7 & 9,4 & 9,5 & 9,5 & 9,5 & 0 & 0,1 & 0 \\
\hline Apartment aqua tatry & *** & 9,6 & 9,7 & 9,3 & 9,3 & 9,4 & 9,5 & 0,1 & 0 & 0,1 \\
\hline Pension vila mery & *** & 9,6 & 9,4 & 9,1 & 9 & 9,3 & 9,3 & $-0,2$ & $-0,1$ & 0 \\
\hline Penzion plesnivec & *** & 9,6 & 9,6 & 8,6 & 9,1 & 8,8 & 8,9 & 0 & 0,5 & 0,1 \\
\hline Penzion borievka & *** & 9,3 & 9,7 & 9 & 9,2 & 9,1 & 9,3 & 0,4 & 0,2 & 0,2 \\
\hline Penzion harmony & $* * *$ & 9,8 & 9,9 & 9,6 & 9,6 & 9,5 & 9,6 & 0,1 & 0 & 0,1 \\
\hline average & & 9,483 & 9,528 & & & 9,206 & 9,228 & & & \\
\hline
\end{tabular}

Source: developed by the authors.

It was again confirmed that, in terms of evaluation development, family businesses perform better than traditional businesses. The overall correlation also suggests that there is a high dependence of the comprehensive evaluation of traditional accommodation facilities on the assessment of staff as such, with a correlation coefficient for 2020 rounded up to 0.895 . And even higher correlation dependence was proved in 2018. The correlation coefficient reached a value of 0.906 . In this case, it is confirmed that the human factor in the provision of tourism services is irreplaceable and significantly affects the overall satisfaction of the client. In the case of family businesses, the dependence of the comprehensive evaluation in 2020 on the staff assessment is lower. The correlation coefficient is rounded to 0.818 . The trend from 2018 was confirmed, the causes of which are used the empirical method, i.e. own experience and observation. Moreover, in 2020 , the overall assessment of satisfaction with services in family tourism businesses is half a point higher on the ten-point scale. A summary of these correlations is given in Table 4.

Table 4. Comparison of correlations of family and non-family companies

\begin{tabular}{ccc}
\hline & $\begin{array}{c}\text { Correlation between final } \\
\text { evaluation index and personnel } \\
\text { evaluation index }\end{array}$ & $\begin{array}{c}\text { Correlation between final } \\
\text { evaluation index and } \\
\text { price/quality index }\end{array}$ \\
\hline Non-family & 0,728745039 & 0,627922918 \\
Family & 0,586709817 & 0,58560605 \\
\hline
\end{tabular}

Source: developed by the authors. 
Based on the above results, it can be stated that the dependence of the overall evaluation of accommodation services in the assessment of staff and the price/quality ratio is higher in traditional accommodation facilties in comparison with family businesses. It follows logically that these companies should pay close attention to the careful selection of employees who come into contact with the client. The selection of quality employees subsequently has an impact on the overall evaluation of the quality of services provided. Authors recommend investing in customer relations, even if the client can feel whether the service is provided with the added value of love and willingness or just as a job. In small family businesses, there is usually no selection of employees, as the participation of family members in the provision of services is assumed. According to statements in the theoretical part of the paper, several authors agree with the opinion that the motivation of family members is usually higher.

Conclusions. Household, resp. family and business are two different entities with a differentiated position within the market mechanism. In the case of a family business, these two seemingly diametrically opposed positions merge into one. Within small and medium-sized tourism enterprises, this distinction is reflected in a difference of up to $5 \%$ in the perception of customer satisfaction in favour of family businesses. This fact could be supported by the management of companies in the spirit of traditional Christian values. The family is a natural desire of every person and evokes a feeling of background, protection, home. The visitor, as the bearer of the demand for tourism services, is primarily a person with his natural desires. Although in the past the prevailing view was that it is a disadvantage to do business with the family due to fears of failure and disruption of family relationships, nowadays more and more attention is being paid to the family business.

For example, the article about the world's most unique study programs (Kluskova, 2016) is stated, that since 1998, there has been a unique study program in DeLand, Florida, at Stetson's Family Enterprise Center called "Family Business», in which students (future founders of family businesses) obtain the necessary managerial skills. For many, a family business is a guarantee of a more accommodating approach to meeting clients' expectations. Based on three years of research, the symbiosis of traditional Christian values and the effective operation of the company in the family environment appears to be a successful prerequisite for customer satisfaction and the competitiveness of family tourism businesses.

Author Contributions: conceptualization, J. P. and Z. G.; methodology, Z. G.; software, M. V and Z. G.; validation, J. P. and Z. G., formal analysis, M. V.; investigation, J. P. and Z. G.; resources, M. V.; data curation, Z. G.; writing—original draft preparation, M. V.; writing - review and editing, M. V., Z. G. and J. P.; visualization, M. V.; supervision, J. P.; funding acquisition, J. P., Z. G. and M. V.

Funding: This article is funded by our private financial sources.

\section{References}

Ahmad, S., Siddiqui, K. A., \& AboAlsamh, H. M. (2020). Family SMEs' survival: the role of owner family and corporate social responsibility. Journal of Small Business and Enterprise Development. [Google Scholar] [CrossRef]

Andreini, D., Bettinelli, C., Pedeliento, G., \& Apa, R. (2020). How do consumers see firms' family nature? A review of the literature. Family Business Review, 33(1), 18-37. [Google Scholar] [CrossRef]

Astrachan, J. H., Astrachan, C. B., Campopiano, G., \& Baù, M. (2020). Values, Spirituality and Religion: Family Business and the Roots of Sustainable Ethical Behavior. Journal of Business Ethics, 1-9. [Google Scholar] [CrossRef]

Bacik, R., Fedorko, R., Gavurova, B., Olearova, M., \& Rigelsky, M. (2020). Hotel Marketing Policy: Role of Rating in Consumer Decision Making. Marketing and management of innovations, 11(1), 11-25. [Google Scholar] [CrossRef]

Belas, J., Demjan, V., Habanik, J., Hudakova, M., \& Sipko, J. (2015). The business environment of small and medium-sized enterprises in selected regions of the Czech Republic and Slovakia. Ekonomie a Management. 18(1), 95-110. [Google Scholar] [CrossRef]

Bujan, I. (2020). Family Business In Tourism Characteristics - the Owners Perspective. Ekonomski pregled, 71(1), 3-32. [Google Scholar] [CrossRef]

Davidaviciene, V., Meidute-Kavaliauskiene, S., \& Paliulis, R. (2019). Research on the influence of social media on generation Y consumer purchase decisions. Marketing and management of innovations, 10 (4), pp. 39-49. [Google Scholar] [CrossRef] 


\section{Z., Goncarova, J., Pitekova, M., Vrablikova. Assessment of the Impact of Selected Satisfaction Parameters on the}

Competitiveness of Family Tourism

Gibb Dyer Jr, W. (2006). Examining the "family effect" on firm performance. Family business review, 19(4), 253-273. [Google Scholar] [CrossRef]

Gucik, M. (2010). Manazment cestovneho ruchu. Banska Bystrica:(EDS DALIBB, sro pre Slovak-Swiss Tourism Banska Bystrica, 2010. Tourism Management.

Gucik, M. (2011). Marketing cestovneho ruchu. Slovak-SwissTourism, Banska Bystrica.

Hanson, S. K., Hessel, H. M., \& Danes, S. M. (2019). Relational processes in family entrepreneurial culture and resilience across generations. Journal of Family Business Strategy, 10(3), 100263. [Google Scholar] [CrossRef]

Heskova, M., \& Vojtko, V. (2008). Rodinne firmy: zdroj regionalniho rozvoje. Profess Consulting.

Klein, S. B. (2004). Familienunternehmen, theoretische und empirische Grundlagen, Wiesbaden: Gabler Verlag. [Google Scholar]

Kluskova, L. (2016). 9 najunikatnejSích Studijných programov na svete. Eduworld. Sk. Retrieved from [Link]

Kotler, Ph., \& Keller, K. L. (2007). Marketing management. Praque, Grada Publishing.

Kozak, V., Stankova, P. (2008). Marketing I. Zlín, UTB.

Kucerova, J., \& Smardova L'. (2016). Podnikanie v cestovnom ruchu. Bratislava, Wolters Kluwer.

Markova, V. (2003). Male a stredne podnikanie v Slovenskej republike. Univerzita Mateja Bela. [Google Scholar]

Moresova, M., \& Sedliacikova, M. (2017). Socialna funkcia rodinných podnikov. Scientia luventa 2017 EF UMB, 281- 290. Retrieved from [Link]

Moresova, M., Sedliacikova, M., \& KaScakova, A. (2020). Global determinants of sustaining and developing family enterprises in Slovakia. In SHS Web of Conferences (Vol. 74, p. 03005). EDP Sciences. [Google Scholar]

Moresova, M., Sedliacikova, M., \& Lorincova, S. (2018). Family business in Slovakia. Podnikova ekonomika a manazment. Vol. 3, No. 2, pp. 79-90. Retrieved from [Link]

Orieska, J. (2010). Sluzby cestovneho ruchu. Bratislava: SPN-Mlade leta, sro.

Payne, A. (1996). Marketing sluzeb. Prague: Grada Publishing.

Pitekova, J. (2017). Prípadova Studia: Rodinne podnikanie v duchu socialnej nauky Cirkvi. Reflexie: Kompendium teorie a praxe podnikania, 1(1), pp.17-22. Retrieved from [Link]

Pitekova, J., Goncarova, Z. (2018). Rodinný podnik ako konkurencna výhoda podnikania v cestovnom ruchu. Hotelnictví, turismus a vzdělavani (Proceedings from International scientific conference). Prague, The Hotel College. Retrieved from [Link]

Porter, M. E. (2008). On competition. Boston, Harward Business School. [Google Scholar]

Ramírez, Y., Dieguez-Soto, J., \& Manzaneque, M. (2020). How does intellectual capital efficiency affect firm performance? The moderating role of family management. International Journal of Productivity and Performance Management. [Google Scholar] [CrossRef

Rasovska, I., \& Ryglova, K. (2017). Management kvality sluzeb v cestovním ruchu. Prague, Grada Publishing. [Google Scholar]

Ravar, A., \& lorgulescu, M. C. (2013). Consumers' perception on innovation in the tourism value chain. Oradea Journal of Business and Economics. 22(1), 815-824. [Google Scholar]

Sediacikova, M., Moresova, M., \& Bencikova, D. (2017). Differences in the organizational structure of family businesses in the Slovak Republic. Global Scientific Conference: Management and Economics in Manufacturing, Zvolen, Slovakia. pp. 52-59. Retrieved from [Link]

Serina, P. (2011). Rodinne podnikanie na Slovensku, Studia, advokatska kancelaria, sro. [Google Scholar]

Slovak Business Agency. (2014). Preco su rodinne podniky na Slovensku neviditel'ne? Retrieved from [Link

Stanley, L. J., Hernandez-Linares, R., Lopez-Fernandez, M. C., \& Kellermanns, F. W. (2019). A typology of family firms: An investigation of entrepreneurial orientation and performance. Family Business Review, 32(2), 174-194. [Google Scholar] [CrossRef] Stefko, R., Dorcak, P., Bacik, R., Ferencova, M., Gburova, J...\& Zajacova, L. (2013). Marketing naSej sucasnosti. PreSov, Bookman.

Strațovska, H., Strațovska, L'., Pachingerova, M., \& Sirotkova, A (2009). Podnikanie. Bratislava, Merkury.

Strazovska, '., Strazovska, H., \& Kroslakova, M. (2008). Podnikanie formou rodinných podnikov. Sprint, Bratislava. [Google Scholar]

Subertova, E. (2009). Podnikanie v malých a stredných podnikoch. Bratislava, Ekonom.

Ubreziova, I., Diacikova, A., Sokil, O., \& Apostol, S. (2020). Innovation Ecosystems for the Moldovan Small and Medium-Sized Enterprises. Marketing and management of innovations, 2, 298-312. [Google Scholar] [CrossRef]

Zahra, S. A. (2016). Developing theory-grounded family business research: Some suggestions. Journal of Family Business Strategy, 7(1), 3-7. [Google Scholar] [CrossRef]

Zakon (5. 7. 2018) Z. z. - polozka 1629 o delení podnikov fyzických osob a iných zariadení suvisiacich s dedením podnikov (Poland). Retrieved from [Link]

Зузана Гончарова, Ph.D., Католицький університет в Ружомберок, Словачччина

Яна Пітекова, Ph.D., Католицький університет в Ружомберок, Словачччина

Марія Враблікова, Католицький університет в Ружомберок, Словачччина

Оцінювання впливу рівня задоволення споживачів на конкурентоспроможність сімейного туризму 
Z., Goncarova, J., Pitekova, M., Vrablikova. Assessment of the Impact of Selected Satisfaction Parameters on the Competitiveness of Family Tourism

У рамках статті досліджено вплив рівня задоволення очікувань клієнта у туристичному секторі сімейного типу. Об'єктом дослідження $є$ відвідувач, як носій попиту на туристичні послуги з індивідуальними характеристиками та вимогами. Головною метою статті $є$ аналіз залежності між обраними параметрами задоволеності клієнтів на прикладі двох груп туристичних компаній. До першої групи віднесено туристичні компанії сімейного типу, до другої групи класичні туристичні компанії. При цьому авторами зазначено, що туристичні компанії сімейного типу мають вищий рівень задоволення клієнтів. Відповідно до мети дослідження авторами проаналізувано залежність рівня задоволеності клієнтів від якості обслуговування персоналом та співвідношенням ціна/якість. Авторамо висунуто гіпотезу, що рівень задоволеність клієнтів залежить від якості їх обслуговування. Емпіричне дослідження проведено на основі панельних даних, сформованих для вибірки з 44 «несімейних» та 18 «сімейних» туристичних компаній. У ході дослідження авторами оцінено якість обслуговування, співвідношення ціна/якість та сформувано загальну оцінку досліджуваних компаній. Періодом дослідження обрано 2018 та 2020 роки. Практичну реалізацію усіх етапів дослідження здійснено за допомогою розрахунку зміни індексів; аналізу часткової кореляції; формування підсумкової кореляційної матрииі, в якій розраховано кореляцію між зміною загальної оцінки та співвідношенням ціна/якість сімейних і несімейних компаній. Основними математично-статистичними методами дослідження є аналіз, синтез, індукиія, аналогія, порівняння та коефіцієнт кореляиії Пірсона. Евристичний підхід передбачає аналіз просресійних наукових джерел з досліджуваної тематики та обробку вторинних даних, отриманих з порталу оренди житла booking.com. За отриманими результатами дослідження встановлено, що коефііцієнти кореляиії у несімейному бізнесі є вищими порівняно до сімейного. Результати оцінювання якості обслуговування підтверджують статистично значущу залежність, оскільки значення коефіцієнту Пірсона $\epsilon$ вищим за 0,7. На основі отриманих результатів авториами зроблено висновок, що несімейним підприємствам варто приділяти більше уваги людському фактору. Встановлено, що знеособлене лідерство та негнучкі організаційні структури є бар'єрами на шляху самореалізації несімейних туристичних компаній. При иьому перевагою сімейних підприємств є відбір співробітників заснований на взаємній довірі.

Ключові слова: конкурентоспроможність, кореляція, задоволеність клієнтів, сімейний бізнес, несімейний бізнес, туризм.

Manuscript received: 14.01.2020

(C) The author(s) 2020. This article is published with open access at Sumy State University

Marketing and Management of Innovations, 2020, Issue 4 